Buletin Ilmiah Math, Stat, dan Terapannya (Bimaster)

Volume 08, No. 2 (2019), hal 185-192.

\title{
PENGUJIAN KORELASI KANONIK PENUMPANG PESAWAT DI BANDAR UDARA INTERNASIONAL SUPADIO
}

\author{
Fery Prastio, Shantika Martha, Hendra Perdana
}

\section{INTISARI}

\begin{abstract}
Analisis korelasi kanonik berguna dalam menguraikan struktur hubungan dari dua kelompok variabel. Penguraian struktur hubungan dilakukan dengan menginterpretasikan muatan silang kanonik untuk mengetahui urutan variabel mana saja dalam sebuah kelompok yang paling berkontribusi terhadap besaran hubungan antara dua kelompok variabel. Pengujian korelasi kanonik pada penelitian ini dilakukan pada data yang berkaitan dengan penerbangan, dimana satu kelompok variabel dependen $\left\{\mathrm{Y}_{\mathrm{q}}\right\}$ yang beranggotakan lima variabel yang memuat data jumlah penumpang bulanan maskapai Kalstar Aviation $\left(\mathrm{Y}_{1}\right)$, Lion Air $\left(\mathrm{Y}_{2}\right)$, Nam Air $\left(\mathrm{Y}_{3}\right)$, Sriwijaya Air $\left(\mathrm{Y}_{4}\right)$ dan Xpress Air $\left(\mathrm{Y}_{5}\right)$ yang dihubungkan dengan sebuah kelompok variabel independen $\left\{\mathrm{X}_{\mathrm{p}}\right\}$ yang beranggotakan lima variabel diantaranya adalah pergerakan pesawat $\left(\mathrm{X}_{1}\right)$, banyaknya wisatawan masuk melalui jalur entikong $\left(\mathrm{X}_{2}\right)$, rata-rata curah hujan $\left(\mathrm{X}_{3}\right)$, proyeksi jumlah penduduk Kalimantan Barat $\left(\mathrm{X}_{4}\right)$, dan indeks harga konsumen $\left(\mathrm{X}_{5}\right)$. Hubungan yang terjadi diantara kedua kelompok variabel tersebut dijelaskan melalui besaran koefisien korelasi kanonik yang dalam penelitian ini menjelaskan bahwa kedua kelompok variabel tersebut berhubungan sangat erat.
\end{abstract}

Kata Kunci: korelasi kanonik, multivariat, analisis penerbangan, bandar udara

\section{PENDAHULUAN}

Indonesia sebagai negara kepulauan dihadapkan pada tantangan yang cukup berat di sektor transportasi. Kondisi tersebut membuat transportasi udara sebagai sarana transportasi paling efektif yang dapat menghubungkan wilayah-wilayah tersebut dengan waktu tempuh yang cepat [1]. Besarnya minat masyarakat terhadap jasa penerbangan yang meningkat setiap tahunnya, melatarbelakangi dilakukannya penelitian ini. Penelitian ini dilakukan dengan menguji kelompok variabel dependen $\left\{\mathrm{Y}_{\mathrm{q}}\right\}$ yang berisikan data jumlah penumpang lima maskapai terhadap kelompok variabel independen $\left\{\mathrm{X}_{\mathrm{p}}\right\}$ yang berisikan variabel yang berkaitan dengan penerbangan menggunakan analisis korelasi kanonik. Analisis korelasi kanonik adalah studi mengenai hubungan antara sekelompok prediktor (variabel independen) dengan sekelompok variabel dependen atau studi mengenai hubungan antara dua pasang vektor [2]. Jenis data yang digunakan pada analisis ini adalah data metrik, yakni data interval atau rasio [3].

Tujuan dari analisis korelasi kanonik adalah membentuk fungsi-fungsi kanonik yang berisikan koefisien korelasi kanonik yang kemudian fungsi tersebut diinterpretasikan agar dapat ditarik kesimpulan bahwa benar adanya korelasi yang terjadi diantara dua kelompok variabel serta mengetahui urutan variabel yang berkontribusi terhadap korelasi tersebut. Pengujian korelasi kanonik dalam penelitian ini tidak melibatkan asumsi klasik, serta tidak membahas bobot kanonik dan muatan kanonik karena sudah diwakili oleh muatan silang kanonik yang lebih sempurna dari kedua cara interpretasi tersebut. Dimulai dengan menstandarisasi data ke bentuk Z-Score, korelasi kanonik dibentuk oleh nilai eigen dan vektor eigen dari matriks varian kovarian yang berasal dari data standarisasi tersebut. Nilai eigen merupakan koefisien korelasi kanonik yang dikuadratkan. Koefisien kanonik selanjutnya diuji menggunakan signifikansi korelasi kanonik dan analisis redundansi untuk akhirnya dapat diinterpretasikan melalui muatan silang kanonik untuk mengetahui urutan variabel 
yang paling berkontribusi terhadap hubungan yang terjadi diantara kedua kelompok variabel yang diujikan.

\section{MATRIKS VARIAN KOVARIAN Z-SCORE}

Langkah awal dalam membentuk matriks varian kovarian adalah menstandarisasi data masingmasing variabel pada kedua kelompok variabel menggunakan Z-Score dimana dalam menghitungnya menggunakan rumus

$$
Z=\frac{\left(x_{n}-\bar{x}\right)}{\sigma}
$$

Pada rumus (1) setiap data dalam sebuah variabel dikurangi dengan rata-rata pada variabel itu sendiri kemudian dibagi dengan standar deviasi pada variabel tersebut. Hasil dari standarisasi memiliki ratarata nol dan varians 1 pada setiap variabelnya. Data dari standarisasi tersebut kemudian dibentuk menjadi matriks varian kovarian dimana dua kelompok variabel yang diuji diantaranya kelompok pertama dari $p$-variabel diwakili oleh (px1) vektor acak X sebagai variabel independen, kelompok kedua dari $q$-variabel diwakili oleh (qx1) vektor acak Y sebagai variabel dependen.

Misalkan untuk vektor acak $\mathrm{X}$ dan $\mathrm{Y}$ :

$$
\begin{array}{ll}
E(X)=\mu_{x} ; & \operatorname{Cov}(X, X)=\Sigma_{11} ; \\
E(Y)=\mu_{y} ; & \operatorname{Cov}(Y, Y)=\Sigma_{22} ;
\end{array}
$$

$\operatorname{Cov}(X, Y)=\sum_{12}=\Sigma_{21}^{\prime}$

Jika dibuat bentuk partisi matriks varian kovarian, maka akan membentuk matriks berikut

$$
\sum=\left[\begin{array}{ll}
\sum_{11} & \sum_{12} \\
\sum_{21} & \sum_{22}
\end{array}\right]
$$

diasumsikan bahwa $\sum_{11}$ dan $\sum_{22}$ adalah matriks nonsingular atau matriks yang memiliki invers, kemudian akan dibentuk akar matriks simetris berupa $\sum_{11}^{1 / 2}$ dan $\sum_{22}^{1 / 2}$ dimana $\sum_{11}=\sum_{11}^{1 / 2} \sum_{11}^{1 / 2}$ dan $\Sigma_{11}^{-1}=\sum_{11}^{-1 / 2} \sum_{11}^{-1 / 2}$

\section{FUNGSI KANONIK DAN KOEFISIEN KORELASI KANONIK}

Koefisien korelasi kanonik dapat dihitung menggunakan rumus

$$
\operatorname{Corr}\left(U_{i}, V_{i}\right)=\rho_{i}^{*}=\frac{\operatorname{Cov}\left(U_{i}, V_{i}\right)}{\sqrt{\operatorname{Var}\left(U_{i}\right)} \sqrt{\operatorname{Var}\left(V_{i}\right)}}
$$

dimana $\boldsymbol{U}$ adalah kombinasi linear variabel independen dengan $\boldsymbol{a}$ sebagai vektor koefisiennya dan $\boldsymbol{V}$ adalah kombinasi linear variabel dependen dengan $\boldsymbol{b}$ sebagai vektor koefisiennya, jadi

sehingga

$$
\begin{aligned}
& \boldsymbol{U}_{\boldsymbol{i}}=\boldsymbol{a}_{\boldsymbol{i}}^{\prime} X \\
& \boldsymbol{V}_{\boldsymbol{i}}=\boldsymbol{b}_{\boldsymbol{i}}^{\prime} Y
\end{aligned}
$$

$$
\begin{aligned}
& \operatorname{Var}\left(\boldsymbol{U}_{\boldsymbol{i}}\right)=\operatorname{Var}\left(\boldsymbol{a}_{\boldsymbol{i}}^{\prime} X\right)=\boldsymbol{a}_{\boldsymbol{i}}^{\prime} \operatorname{cov}(X, X) \boldsymbol{a}_{\boldsymbol{i}}=\boldsymbol{a}_{\boldsymbol{i}}^{\prime} \sum_{11} \boldsymbol{a}_{\boldsymbol{i}} \\
& \operatorname{Var}\left(\boldsymbol{V}_{\boldsymbol{i}}\right)=\operatorname{Var}\left(\boldsymbol{b}_{\boldsymbol{i}}^{\prime} Y\right)=\boldsymbol{b}_{\boldsymbol{i}}^{\prime} \operatorname{cov}(Y, Y) \boldsymbol{b}_{\boldsymbol{i}}=\boldsymbol{b}_{\boldsymbol{i}}^{\prime} \sum_{22} \boldsymbol{b}_{\boldsymbol{i}} \\
& \operatorname{Cov}\left(\boldsymbol{U}_{\boldsymbol{i}}, \boldsymbol{V}_{\boldsymbol{i}}\right)=\operatorname{Cov}\left(\boldsymbol{a}_{\boldsymbol{i}}^{\prime} X, \boldsymbol{b}_{\boldsymbol{i}}^{\prime} Y\right)=\boldsymbol{a}_{\boldsymbol{i}}^{\prime} \operatorname{cov}(X, Y) \boldsymbol{b}_{\boldsymbol{i}}=\boldsymbol{a}_{\boldsymbol{i}}^{\prime} \sum_{12} \boldsymbol{b}_{\boldsymbol{i}}
\end{aligned}
$$

Maka

$$
\operatorname{Corr}\left(\boldsymbol{U}_{\boldsymbol{i}}, \boldsymbol{V}_{\boldsymbol{i}}\right)=\rho_{i}^{*}=\frac{a_{i}^{\prime} \Sigma_{12} b_{i}}{\sqrt{a_{i}^{\prime} \Sigma_{11} a_{i}} \sqrt{b_{i}^{\prime} \Sigma_{22} b_{i}}}
$$

nilai $\operatorname{Cor}\left(\boldsymbol{U}_{\boldsymbol{i}}, \boldsymbol{V}_{\boldsymbol{i}}\right)$ dengan fungsi kanonik $\mathrm{i}=1,2, \ldots, \mathrm{k}$, merupakan koefisien korelasi kanonik yang nilainya akan sama dengan akar dari nilai eigen $(\sqrt{\lambda})$ dimana $\lambda_{i}=\rho_{i}^{* 2}$, sehingga dapat dituliskan

$$
\operatorname{Corr}\left(\boldsymbol{U}_{\boldsymbol{i}}, \boldsymbol{V}_{\boldsymbol{i}}\right)=\rho_{i}^{*}=\sqrt{\lambda_{i}}
$$

Langkah pertama yang dilakukan adalah menghitung $\operatorname{Var}\left(\boldsymbol{U}_{\boldsymbol{i}}\right)$ dengan melakukan perkalian matriks 
$\sum_{11}^{-1 / 2} \sum_{12} \sum_{22}^{-1} \sum_{21} \sum_{11}^{-1 / 2}$ yang nantinya hasil akhir dari perkalian matriks tersebut dilakukan perhitungan nilai eigen dan vektor eigen sehingga menghasilkan nilai eigen $\rho_{1}^{* 2} \geq \rho_{2}^{* 2} \geq \ldots \geq \rho_{k}^{* 2}$ yang merupakan koefisien kanonik kuadrat, serta vektor eigen $\boldsymbol{e}_{1}, \boldsymbol{e}_{2}, \ldots, \boldsymbol{e}_{\boldsymbol{k}}$ yang digunakan untuk mencari vektor koefisien $\boldsymbol{a}$.

Sementara untuk menghitung $\operatorname{Var}\left(\boldsymbol{V}_{i}\right)$ dilakukan perkalian matriks $\sum_{22}^{-1 / 2} \sum_{21} \sum_{11}^{-1} \sum_{12} \sum_{22}^{-1 / 2}$, yang akan memiliki nilai eigen $\rho_{1}^{* 2} \geq \rho_{2}^{* 2} \geq \ldots \geq \rho_{k}^{* 2}$ yang sama dengan nilai eigen pada perhitungan $\operatorname{Var}\left(\boldsymbol{U}_{\boldsymbol{i}}\right)$, namun dengan vektor eigen yang berbeda, dimana pada $\operatorname{Var}\left(\boldsymbol{V}_{\boldsymbol{i}}\right)$ vektor eigen tersebut dinotasikan dengan $f_{1}, f_{2}, \ldots, f_{k}$ yang digunakan untk mencari vektor koefisien $\boldsymbol{b}$.

Setelah menemukan vektor eigen $e_{1}, e_{2}, \ldots, e_{k}$ dan vektor eigen $f_{1}, f_{2}, \ldots, f_{k}$, maka vektor koefisien $a$ dan $\boldsymbol{b}$ dapat diperoleh dengan rumus sebagai berikut:

$$
\begin{array}{cc}
a_{1}^{\prime}=e_{1}^{\prime} \sum_{11}^{-1 / 2} & b_{1}^{\prime}=f_{1}^{\prime} \sum_{22}^{-1 / 2} \\
a_{2}^{\prime}=e_{2}^{\prime} \sum_{11}^{-1 / 2} & b_{2}^{\prime}=f_{2}^{\prime} \sum_{22}^{-1 / 2} \\
\vdots & \vdots \\
a_{k}^{\prime}=e_{k}^{\prime} \sum_{11}^{-1 / 2} & b_{k}^{\prime}=f_{k}^{\prime} \sum_{22}^{-1 / 2}
\end{array}
$$

dimana $\boldsymbol{a}_{\boldsymbol{1}}^{\prime}$ merupakan vektor koefisien independen pertama yang digunakan untuk menghitung $\operatorname{Var}\left(\boldsymbol{U}_{\boldsymbol{1}}\right)$ dan dihasilkan dari perkalian antara vektor eigen pertama yang ditransposkan $\left(\boldsymbol{e}_{\boldsymbol{1}}^{\prime}\right)$ dengan akar matriks negatif dari matriks $\operatorname{Cov}(X, X)$. Sedangkan $\boldsymbol{b}_{\boldsymbol{1}}^{\prime}$ merupakan vektor koefisien dependen pertama yang digunakan untuk menghitung $\operatorname{Var}\left(\boldsymbol{V}_{\boldsymbol{l}}\right)$ dan dihasilkan dari perkalian antara vektor eigen pertama yang ditransposkan $\left(f_{\boldsymbol{I}}^{\prime}\right)$ dengan akar matriks negatif dari matriks $\operatorname{Cov}(Y, Y)$ [4].

\section{PENGUJIAN SIGNIFIKANSI KORELASI KANONIK}

Pengujian signifikansi korelasi kanonik dapat dihitung menggunakan wilks lambda F-Test dengan tahapan sebagai berikut:

Menentukan Hipotesis:

$\mathrm{H}_{0}=$ Tidak ada fungsi yang mewakili hubungan kedua kelompok variabel

$\mathrm{H}_{1}=$ Fungsi yang diujikan mewakili hubungan kedua kelompok variabel

dengan kriteria pengujian tolak $\mathrm{H}_{0}$ jika Wilks Lambda F-Test $>\mathrm{F}_{\alpha}$, pengujian signifikansi korelasi kanonik dimulai dengan uji signifikansi secara keseluruhan yang diwakili oleh pengujian signifikansi fungsi pertama kemudian dilanjutkan dengan uji signifikansi secara sebagian yang dimulai dengan uji signifikansi fungsi kedua hingga fungsi ke- $k$.

1. Uji Signifikansi Secara Keseluruhan

Statistik uji signifikansi keseluruhan dimulai dari pengujian signifikansi fungsi pertama:

dimana:

$$
F=\frac{1-\Lambda_{1}{ }^{1 / t}}{\Lambda_{1}{ }^{1 / t}} \frac{d f_{2}}{d f_{1}}
$$

$$
\begin{aligned}
& \Lambda_{1}=\prod_{i=1}^{k}\left(1-\rho_{i}^{2}\right) \\
& d f_{1}=p q \\
& d f_{2}=\left[n-\frac{1}{2}(p+q+3)\right] t-\frac{1}{2} p q+1 \\
& t=\sqrt{\frac{p^{2} q^{2}-4}{p^{2}+q^{2}-5}}
\end{aligned}
$$


2. Uji Signifikansi Secara Sebagian

Jika pengujian signifikansi kanonik fungsi secara keseluruhan yang diwakili oleh uji signifikansi fungsi pertama signifikan, maka analisis dapat dilanjutkan ke uji signifikansi sebagian yang dimulai dari fungsi kedua hingga fungsi ke- $k$ dengan statistik uji signifikansi secara sebagian berikut:

$$
F=\frac{1-\Lambda_{r}^{1 / t}}{\Lambda_{r}^{1 / t}} \frac{d f_{2}}{d f_{1}}
$$

dimana:

$$
\begin{aligned}
\Lambda_{r} & =\prod_{i=r}^{k}\left(1-\rho_{r}^{2}\right) \\
d f_{1} & =(p-r+1)(q-r+1) \\
d f_{2} & =\left[n-\frac{1}{2}(p+q+3)\right] t-\frac{1}{2} p q+1 \\
t & =\sqrt{\frac{(p-r+1)^{2}(q-r+1)^{2}-4}{(p-r+1)^{2}+(q-r+1)^{2}-5}}
\end{aligned}
$$

dengan:

$n$ = banyaknya pengamatan

$p$ = banyaknya anggota kelompok variabel independen

$q$ = banyaknya anggota kelompok variabel dependen

$r \quad=$ nomor fungsi yang diujikan

$k=\min (\mathrm{p}, \mathrm{q})$

Jika pengujian korelasi kanonik signifikan, maka fungsi yang lolos uji signifikansi tersebut sudah layak dilakukan interpretasi fungsi kanonik yang dapat ditarik sebagai kesimpulan [5].

\section{ANALISIS REDUNDANSI}

Analisis redundansi memuat hasil berupa varians bersama dan indeks redundansi, dengan varians bersama yang dapat dicari menggunakan

$$
\begin{aligned}
& S V_{x U}=\frac{L_{x l}^{2}+L_{x 2}^{2}+\ldots+L_{x p}^{2}}{p} \\
& S V_{y V}=\frac{L_{y 1}^{2}+L_{y 2}^{2}+\ldots+L_{y q}^{2}}{q}
\end{aligned}
$$

dengan:

$S V_{x U}=$ varians bersama ke-U dari kelompok variabel independen

$S V_{y V}=$ varians bersama ke- $\mathrm{V}$ dari kelompok variabel dependen

$L_{x U p}^{2}=$ muatan kanonik kuadrat ke- $p$ dari kelompok variabel independen

$L_{y V q}^{2}=$ muatan kanonik kuadrat ke- $q$ dari kelompok variabel dependen

Indeks redundansi $\left(\mathrm{R}_{\mathrm{I}}\right)$ dicari dengan mengalikan nilai varians bersama terhadap koefisien kanonik kuadrat. Besarnya varians bersama menunjukkan baik atau tidaknya jumlah variabel yang dipilih. Batasan nilai varians bersama bersifat relatif, sebagai rujukan yang cukup baik yaitu sebesar 25\%. [6]

\section{MUATAN SILANG KANONIK}

Muatan silang kanonik dapat dihitung dari perkalian koefisen korelasi kanonik dengan muatan kanonik. Muatan silang kanonik menjelaskan variabel mana saja yang paling berkontribusi terhadap besarnya koefisien korelasi kanonik yang terjadi diantara kedua kelompok variabel. [7]

\section{STUDI KASUS}

Pengambilan data dilakukan di Branch Office Angkasa Pura II Bandar Udara Internasional Supadio yang setiap variabelnya memiliki 30 data dan merupakan data bulanan yang dimulai dari Maret 2015 
hingga Agustus 2017. Data tersebut memuat jumlah penumpang bulanan 5 maskapai diantaranya Kalstar Aviation $\left(\mathrm{Y}_{1}\right)$, Lion Air $\left(\mathrm{Y}_{2}\right)$, Nam Air $\left(\mathrm{Y}_{3}\right)$, Sriwijaya Air $\left(\mathrm{Y}_{4}\right)$, dan Xpress Air $\left(\mathrm{Y}_{5}\right)$, serta kelompok variabel independen yang juga terkait dengan penerbangan $\left\{\mathrm{X}_{\mathrm{p}}\right\}$ yang memuat data pergerakan pesawat $\left(\mathrm{X}_{1}\right)$, banyaknya wisatawan masuk melalui jalur Entikong $\left(\mathrm{X}_{2}\right)$, rata-rata curah hujan $\left(\mathrm{X}_{3}\right)$, proyeksi jumlah penduduk Kalimantan $\operatorname{Barat}\left(\mathrm{X}_{4}\right)$, dan indeks harga konsumen $\left(\mathrm{X}_{5}\right)$.

Tabel 1 Koefisien Korelasi Kanonik

\begin{tabular}{|c|c|c|c|}
\hline Fungsi & $\begin{array}{c}\text { Model } \\
\operatorname{Corr}\left(\mathbf{U}_{\mathbf{i}}, \mathbf{V}_{\mathbf{i}}\right)\end{array}$ & $\begin{array}{c}\text { Korelasi Kanonik } \\
\rho_{1}^{*}\end{array}$ & $\begin{array}{c}\text { Korelasi Kanonik Kuadrat } \\
\rho_{1}^{* 2}\end{array}$ \\
\hline \multirow{2}{*}{1} & $\frac{a_{1}^{\prime} \sum_{12} b_{1}}{2}$ & \multirow{2}{*}{0,976} & \multirow{2}{*}{0,953} \\
\hline & $\sqrt{a_{1}^{\prime} \Sigma_{11} a_{1} \sqrt{b_{1}^{\prime}} \Sigma_{22} b_{1}}$ & & \\
\hline \multirow{2}{*}{2} & $\mathrm{a}_{2} \sum_{12} \mathrm{~b}_{2}$ & \multirow{2}{*}{0,861} & \multirow{2}{*}{0,739} \\
\hline & $\sqrt{a_{2} \Sigma_{11} a_{2} \sqrt{b_{2}} \sum_{22} b_{2}}$ & & \\
\hline \multirow{2}{*}{3} & $\frac{a_{3}^{\prime} \sum_{12} b_{3}}{\square}$ & \multirow{2}{*}{0,537} & \multirow{2}{*}{0,289} \\
\hline & $\sqrt{a_{3}^{\prime} \sum_{11} a_{3} \sqrt{b_{3}^{\prime}} \sum_{22} b_{3}}$ & & \\
\hline \multirow{2}{*}{4} & $\mathrm{a}_{4}^{\prime} \sum_{12} \mathrm{~b}_{4}$ & \multirow{2}{*}{0,151} & \multirow{2}{*}{0,023} \\
\hline & 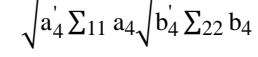 & & \\
\hline \multirow{2}{*}{5} & $a_{5}^{\prime} \sum_{12} b_{5}$ & \multirow{2}{*}{0,047} & \multirow{2}{*}{0,002} \\
\hline & $\sqrt{a_{5}^{\prime} \Sigma_{11} a_{5} \sqrt{b_{5}^{\prime}} \Sigma_{22} b_{5}}$ & & \\
\hline
\end{tabular}

Pada Tabel 1 terdapat dua fungsi yang memiliki koefisien korelasi kanonik yang sangat tinggi yaitu pada fungsi 1 dengan koefisien korelasi kanonik sebesar 0,976 yang menunjukkan hubungan kanonik sebesar 95,3\% antara kelompok variabel dependen dan kelompok variabel independen. Fungsi 2 dengan koefisien korelasi kanonik sebesar 0,861 yang menunjukkan hubungan kanonik sebesar 73,9\% antara kedua kelompok variabel. Oleh karena itu, fungsi 1 dan fungsi 2 menunjukkan secara nyata hubungan derajat yang tinggi antar kedua kelompok variabel, sedangkan fungsi ketiga hingga fungsi kelima memiliki koefisien korelasi kanonik yang rendah, sehingga fungsi-fungsi tersebut tidak dapat digunakan untuk interpretasi fungsi kanonik sebagai penarikan kesimpulan.

Setelah terbentuk 5 fungsi dengan masing-masing koefisien kanonik yang berbeda, dapat dilakukan pengujian signifikansi pada kelima fungsi tersebut dengan uji signifikansi yang pertama adalah uji signifikansi keseluruhan dimana ada dua cara dalam membaca hasil pada uji signifikansi keseluruhan, pertama dengan melihat Sig.F (P-value) dari Pillais, Hottelings, dan Wilks Lambda yang harus bernilai dibawah 0,05. Kedua, melihat Wilks Lambda F-Test fungsi pertama, jika fungsi pertama lolos uji signifikansi, artinya secara keseluruhan sudah ada satu fungsi yang memenuhi syarat untuk diinterpretasikan, sehingga signifikansi fungsi pertama dapat mewakili uji signifikansi kanonik secara keseluruhan dimana hasilnya pada Tabel 4 sebagai berikut:

Tabel 2 Signifikansi Kanonik Keseluruhan

\begin{tabular}{crrrcc}
\hline Pengujian & df $_{\mathbf{1}}$ & \multicolumn{1}{c}{ df $_{\mathbf{2}}$} & F-Test & $\begin{array}{c}\text { Sig.F } \\
(\mathbf{P} \text {-value })\end{array}$ & Hasil \\
\hline Pillais & 25 & 120,0 & 3,217 & 0,000 & Signifikan \\
Hotellings & 25 & 92,0 & 17,321 & 0,000 & Signifikan \\
Wilks Lambda & 25 & 75,8 & 7,908 & 0,000 & Signifikan \\
\hline
\end{tabular}

Dapat diketahui dari Tabel 2 bahwa Sig.F (P-Value) dari pengujian Pillais dan Hottelings bernilai 0,000 yang berada di bawah taraf signifikansi $\alpha_{0,05}$ yang artinya secara keseluruhan, dari 5 fungsi yang 
terbentuk, setidaknya ada 1 fungsi yang lolos signifikansi. Selain itu, pengujian signifikansi fungsi pertama juga dapat dilakukan untuk mewakili uji signifikansi kanonik secara keseluruhan, dimana Wilks Lambda F-Test pada fungsi pertama bernilai 7,908 yang berada diatas F-tabel yang sebesar 2,76 atau Sig.F (P-Value) yang bernilai 0,000 yang berada dibawah $\alpha(0,05)$ yang artinya fungsi pertama sudah lolos uji signifikansi, sehingga fungsi tersebut sudah layak untuk dilakukan interpretasi fungsi kanonik untuk selanjutnya ditarik kesimpulan.

Setelah dilakukan uji signifikansi kanonik keseluruhan dan lolos pada uji tersebut dimana pengujian signifikansi fungsi pertama sudah terwakili pada uji signifikansi keseluruhan, sehingga pengujian signifikansi kanonik sebagian dapat dilanjutkan mulai dari pengujian signifikansi fungsi kedua sampai fungsi ke- $k$ dengan cara yang sama seperti pengujian signifikansi pertama yaitu dengan membandingkan Sig.F dengan $\alpha(0,05)$, atau Wilks Lambda-F-Test dengan F-tabel. Hasil pengujian pada masing-masing fungsi dapat dilihat pada Tabel 3 sebagai berikut:

Tabel 3 Signifikansi Kanonik Sebagian

\begin{tabular}{rrrrrr}
\hline Fungsi & $\mathbf{d f}_{\mathbf{1}}$ & $\mathbf{d f}_{\mathbf{2}}$ & F-Test & $\begin{array}{c}\text { Sig.F } \\
\text { (P-value) }\end{array}$ & \multicolumn{1}{c}{ Hasil } \\
\hline 1 & 25 & 75,80 & 7,908 & 0,000 & Signifikan \\
2 & 16 & 64,79 & 3,038 & 0,001 & Signifikan \\
3 & 9 & 53,69 & 0,970 & 0,475 & Tidak \\
4 & 4 & 46,00 & 0,147 & 0,963 & Tidak \\
5 & 1 & 24,00 & 0,053 & 0,819 & Tidak \\
\hline
\end{tabular}

Pada Tabel 3, dapat diketahui bahwa Wilks Lambda F-Test fungsi 3 hingga fungsi 5 berada di bawah $F_{\alpha: 0,05}=2,76$ atau Sig.F (P-Value) bernilai diatas $\alpha_{0,05}$, sehingga fungsi tersebut tidak lolos uji signifikansi sebagian yang berarti tidak dapat mewakili hubungan antara kelompok variabel. Sedangkan fungsi 1 dan fungsi 2 memiliki nilai Wilks Lambda F-Test diatas 2,76 atau Sig.F (P-Value) bernilai di bawah $\alpha(0,05)$ yang artinya kedua fungsi tersebut dapat mewakili hubungan antar kelompok variabel karena lolos uji signifikansi keseluruhan dan sebagian.

Setelah uji signfikinasi dilakukan, kemudian dapat dilakukan analisis redundansi yang memuat indeks redundansi dan varians bersama, hasilnya pada Tabel 4 sebagai berikut:

Tabel 4 Proporsi Varians

\begin{tabular}{crr}
\hline Fungsi & $\begin{array}{r}\text { Varian } \\
\text { s Bersama }\end{array}$ & $\begin{array}{c}\text { Indeks } \\
\text { Redundansi }\end{array}$ \\
\hline 1 & 0,665 & 0,634 \\
2 & 0,540 & 0,399 \\
3 & 0,186 & 0,054 \\
4 & 0,262 & 0,006 \\
5 & 0,345 & 0,000 \\
\hline
\end{tabular}

Pada Tabel 4 fungsi 1 dan fungsi 2 memiliki indeks redundansi dan varians bersama diatas ambang batas minimal 25\%. Sedangkan fungsi 3 hingga fungsi 5 memiliki indeks redundansi dan varians bersama yang relatif lebih kecil, sehingga berdasarkan analisis redundansi, fungsi 1 dan fungsi 2 sudah mewakili secara nyata hubungan yang terjadi diantara kedua kelompok variabel yang diujikan.

Selanjutnya, fungsi 1 dan fungsi 2 yang sudah lolos uji signifikansi dan memiliki indeks redundansi serta varians bersama yang cukup baik, dapat diinterpretasikan dengan muatan silang kanonik yang dapat dihitung dari perkalian antara muatan kanonik dengan koefisien korelasi kanonik, oleh karena 
itu muatan silang kanonik digunakan untuk penarikan kesimpulan karena tidak memiliki kelemahan seperti bobot kanonik dan merupakan penyempurnaan dari muatan kanonik. Adapun penjelasan hubungan antara kedua kelompok variabel berdasarkan muatan silang kanonik, dijelaskan pada Tabel 5 berikut:

Tabel 5 Muatan Silang Kanonik

\begin{tabular}{|crr|crr|}
\hline Dependen & Fungsi 1 & Fungsi 2 & Independen & Fungsi 1 & Fungsi 2 \\
\hline KD $\left(\mathrm{Y}_{1}\right)$ & $-0,437$ & 0,607 & PP $\left(\mathrm{X}_{1}\right)$ & 0,453 & 0,630 \\
JT $\left(\mathrm{Y}_{2}\right)$ & 0,899 & 0,244 & $\mathrm{WM}\left(\mathrm{X}_{2}\right)$ & $-0,098$ & 0,357 \\
$\mathrm{IN}\left(\mathrm{Y}_{3}\right)$ & $-0,281$ & 0,546 & RCH $\left(\mathrm{X}_{3}\right)$ & 0,180 & 0,004 \\
$\mathrm{SJ}\left(\mathrm{Y}_{4}\right)$ & 0,149 & 0,652 & ProPen $\left(\mathrm{X}_{4}\right)$ & 0,961 & $-0,088$ \\
$\mathrm{XN}\left(\mathrm{Y}_{5}\right)$ & 0,069 & 0,557 & IHK $\left(\mathrm{X}_{5}\right)$ & 0,945 & $-0,062$ \\
\hline
\end{tabular}

Model kanonik pada pasangan pertama dari muatan silang kanonik:

$\mathrm{R}_{\mathrm{X}} \mathrm{V}_{1}=0,453 \mathrm{X}_{1}-0,098 \mathrm{X}_{2}+0,180 \mathrm{X}_{3}+0,961 \mathrm{X}_{4}+0,945 \mathrm{X}_{5}$

$\mathrm{R}_{\mathrm{Y}} \mathrm{U}_{1}=-0,437 \mathrm{Y}_{1}+0,899 \mathrm{Y}_{2}-0,281 \mathrm{Y}_{3}+0,149 \mathrm{Y}_{4}+0,069 \mathrm{Y}_{5}$

Model kanonik pada pasangan kedua dari muatan silang kanonik:

$\mathrm{R}_{\mathrm{X}} \mathrm{V}_{2}=0,630 \mathrm{X}_{1}+0,357 \mathrm{X}_{2}+0,004 \mathrm{X}_{3}-0,088 \mathrm{X}_{4}-0,062 \mathrm{X}_{5}$

$\mathrm{R}_{\mathrm{Y}} \mathrm{U}_{2}=0,607 \mathrm{Y}_{1}+0,244 \mathrm{Y}_{2}+0,546 \mathrm{Y}_{3}+0,652 \mathrm{Y}_{4}+0,557 \mathrm{Y}_{5}$

Pada fungsi 1, urutan variabel yang paling berkontribusi terhadap hubungan yang terjadi diantara kedua kelompok variabel dimulai dari $\mathrm{Y}_{2}, \mathrm{Y}_{1}, \mathrm{Y}_{3}, \mathrm{Y}_{4}$, dan $\mathrm{Y}_{5}$ pada variabel dependennya, serta $\mathrm{X}_{4}, \mathrm{X}_{5}, \mathrm{X}_{1}, \mathrm{X}_{3}$, dan $\mathrm{X}_{2}$ pada variabel independennya. Sedangkan pada fungsi 2 , urutan variabel yang paling berkontribusi terhadap hubungan yang terjadi diantara kedua kelompok variabel dimulai dari $\mathrm{Y}_{4}, \mathrm{Y}_{1}, \mathrm{Y}_{5}, \mathrm{Y}_{3}$, dan $\mathrm{Y}_{2}$ pada variabel dependennya, serta $\mathrm{X}_{1}, \mathrm{X}_{2}, \mathrm{X}_{4}, \mathrm{X}_{5}$, dan $\mathrm{X}_{3}$ pada variabel independennya.

Pada Tabel 5, kesenjangan nilai muatan silang kanonik pada fungsi 1 sangat terlihat dimana pada kelompok variabel dependen, hanya didominasi oleh Lion air (JT) yang memiliki muatan silang kanonik sangat tinggi, selain itu adanya muatan silang kanonik yang bernilai negatif pada variabel Kalstar (KD) dan Nam Air (IN), serta muatan silang kanonik yang sangat kecil pada Sriwijaya Air (SJ) dan Xpress Air (XN) menyebabkan ketidakkonsistenan pengaruh jumlah penumpang terhadap besarnya hubungan antara kedua kelompok variabel, seharusnya seluruh variabel dependen memiliki muatan silang kanonik yang bernilai positif karena kelima variabel tersebut sama-sama variabel yang terkait dengan jumlah penumpang. Berbeda halnya dengan fungsi 2 dimana variabel dependen tidak memiliki kesenjangan nilai muatan silang kanonik yang terlalu besar, sehingga sangat baik jika digunakan untuk menjelaskan hubungan yang terjadi antara kelompok variabel dependen dan independen.

Sama halnya dengan variabel dependen, kesenjangan nilai muatan silang kanonik fungsi 1 juga terjadi pada kelompok variabel independen, dimana pada fungsi 1 didominasi oleh proyeksi jumlah penduduk Kalimantan Barat dan indeks harga konsumen yang sangat tinggi atau nyaris sempurna, sedangkan untuk variabel pergerakan pesawat yang menjadi vital dari adanya penumpang hanya memiliki muatan silang kanonik berukuran sedang diikuti rata-rata curah hujan yang bermuatan silang kanonik sangat kecil. Selain itu, wisatawan masuk bermuatan silang kanonik negatif. Seharusnya, pergerakan pesawat yang menjadi vital dari pengangkutan penumpang, berhubungan lebih dekat 
terhadap koefisien korelasi kanonik, diikuti oleh wisatawan mancanegara yang masuk melalui jalur Entikong yang sebagian diantaranya pasti menggunakan jasa penerbangan di Bandar Udara Internasional Supadio, serta rata-rata curah hujan yang sangat kecil sekali pengaruhnya terhadap koefisien korelasi kanonik dan terakhir diikuti oleh proyeksi penduduk dan indeks harga konsumen yang bernilai negatif.

\section{PENUTUP}

Dari lima fungsi yang terbentuk, fungsi 2 digunakan sebagai dasar penarikan kesimpulan. Fungsi 2 memiliki koefisien korelasi kanonik yang sangat besar serta lolos uji signifikansi kanonik dan memiliki varians bersama serta indeks redundansi diatas ambang batas. Berdasarkan muatan silang kanonik, urutan variabel independen yang paling berkontribusi terhadap besarnya jumlah penumpang dimulai dari pergerakan pesawat sebagai alat angkut penumpang, karena faktanya jika tidak ada pesawat yang terbang maka tidak akan ada penumpang, kemudian wisatawan mancanegara yang masuk melalui jalur entikong yang turut serta menjadi penumpang itu sendiri, diikuti proyeksi jumlah penduduk Kalimantan Barat, Indeks Harga Konsumen dan rata-rata curah hujan yang tidak memiliki pengaruh besar.

\section{DAFTAR PUSTAKA}

[1]. Badan Pusat Statistik (BPS). Statistik Angkutan Udara Kalimantan Barat 2016 [publikasi online]. Jakarta: Badan Pusat Statistik; 2017 [cited 2018 Januari 20]. Available from: Publikasi Badan Pusat Statistik.

[2]. Gudono. Analisis Data Multivariat Edisi Keempat. Yogyakarta: BPFE; 2016.

[3]. Asbah.M.F, Sudarno, Safitri.D. Penentuan Koefisien Korelasi Kanonik dan Interpretasi Fungsi Kanonik Multivariat. Jurnal Gaussian. 2013; 2(2): 119-128.

[4]. Johnson RA, Wichern. Applied Multivariate Statistical Analysis, $4^{\text {th }}$ Edition. New Jersey: Prentice-Hall, Inc; 1998.

[5]. Rencher AC. 2012. Methods of Multivariate Analysis, $3^{\text {rd }}$ Edition. Canada: A John Wiley \& Sons, Inc; 2012.

[6]. Keramati A, Behmanesh I. Assessing the Effects of Information Technology on Firm Performance Using Canonical Correlation Analysis: A Survey in Iran Car Part Supplier Sector. World Academy of Science. 2010; 6(4): 497-513.

[7]. Hair JF, Black WC, Babin BJ, Anderson RE. Multivariate Data Analysis, $5^{\text {th }}$ Edition. New Jersey: Prentice Hall, Inc; 1998.

FERY PRASTIO

SHANTIKA MARTHA

HENDRA PERDANA
: Jurusan Matematika FMIPA UNTAN, Pontianak feriprasetio@planetmail.net

: Jurusan Matematika FMIPA UNTAN, Pontianak shantika.martha@math.untan.ac.id

: Jurusan Matematika FMIPA UNTAN, Pontianak hendra.perdana@math.untan.ac.id 